\title{
Na corrente midiática da fé: comunicação de massa e dinâmicas contemporâneas do testemunho evangélico
}

In the media stream of faith: mass communication and contemporary dynamics of evangelical testimony

Raphael Bispo*

* Universidade Federal de Juiz de Fora - Juiz de Fora, MG, Brasil raphaelbispo83@gmail.com 


\title{
Resumo
}

Diante da emergência de inúmeras artistas que compõem a cultura popular se declarando evangélicas na atualidade, o objetivo principal deste artigo é investigar os sentidos, estilos e efeitos de suas narrativas testemunhais. Mais precisamente, busco analisar como diferentes dispositivos midiáticos (livros, televisão, internet) agem na produção de suas subjetividades religiosas, verificando assim como se efetivam as relações do pentecostalismo com os meios de comunicação de massa nos dias de hoje. A partir do estudo de caso de uma celebridade evangélica, procuro analisar como as tecnologias comunicativas oferecem novos significados à maneira como comumente conhecemos a manifestação desses típicos atos de fala cristãos. Além disso, se constatará também o quanto o universo da família torna-se importante no auxílio da construção dessas narrativas de testemunho, graças a uma série de conexões midiáticas estabelecida entre aquele que narra e sua parentela.

Palavras-chave: testemunhos; meios de comunicação; conversão religiosa; família.

\begin{abstract}
In the face of the emergence of countless artists who constitute popular culture declaring themselves evangelicals, the main objective of this article is to investigate the meanings, styles and effects of their testimony narratives. More precisely, we seek to analyze how different media devices (books, television, internet) act in the production of their religious subjectivities, verifying how effective are the relations of pentecostalism with the mass media in the present day. Based on the case study of an evangelical celebrity, we seek to analyze more specifically how communicative technologies offer other meanings as we commonly know the manifestation of these typical Christian speech acts. In addition, we will also find out how the family universe becomes important in the construction of these witness narratives, thanks to a series of media connections established between the narrator and his kinship.
\end{abstract}

Keywords: testimony; media; religion conversion; family. 
Só há dois tipos de pessoas no mundo: As que entretêm $E$ as que observam Britney Spears, "Circus"

\section{Introdução}

Nos últimos anos, tem ganhado amplo destaque na sociedade brasileira a presença maciça na cena pública de inúmeras artistas evangélicas, isto é, atrizes, cantoras, dançarinas e modelos do mundo artístico-popular que passaram por recentes conversões religiosas, em sua grande maioria a vertentes (neo)pentecostais. Tal expressão "artista evangélica" contém em si mesma os paradoxos e ambiguidades que marcam as experiências religiosas na contemporaneidade ao conseguir conciliar discursivamente o "equilíbrio de antagonismos" (Teixeira, C., 2011, p. 45) entre dois mundos que, em princípio, parecem estar completamente afastados: o mundo artístico e suas incitações à diversão, à exposição de si e à frivolidade descompromissada em contraste com o espaço da intimidade pentecostal e suas ditas práticas de restrições comportamentais e morais.

A aparente contradição de uma simples expressão como "artistas evangélicas" guarda também em seu interior um fenômeno que ganha relevo na atualidade, alvo da preocupação deste artigo: a importância que os testemunhos religiosos enquanto estilos narrativos vêm adquirindo na esfera midiática diante do crescimento do pentecostalismo no Brasil. Nomear por meio de uma única expressão a convivência de contraditórios é atestar a capacidade dos discursos testemunhais de realçar as "transformações" subjetivas vivenciadas por certas pessoas. E se em princípio se converter nos remete à esfera da intimidade, tais experiências das artistas evangélicas têm invadido os mais diferentes veículos de comunicação de massa através de uma ampla produção editorial e audiovisual de mensagens de "transformação". Portanto, os testemunhos dessas artistas fazem-se presentes não só nos espaços das igrejas, mas em programas de televisão, rádios, livros e produtos digitais como DVDs, em canais de internet e nas redes sociais.

Diante da emergência de inúmeras artistas que compõem a cultura popular se declarando evangélicas, o objetivo principal deste texto é investigar 
os sentidos, estilos e efeitos de suas narrativas testemunhais. ${ }^{1}$ Mais precisamente, busco analisar como diferentes dispositivos midiáticos (como os livros, os canais de internet, a televisão e as redes sociais) agem na produção de suas subjetividades religiosas, verificando assim como se efetivam as relações do pentecostalismo com os meios de comunicação de massa nos dias de hoje. Compreendendo o testemunho como um gênero de narração de histórias de vida com características próprias, a principal hipótese aqui desenvolvida é de que sua midiatização tem promovido o surgimento de novas e inusitadas formas de proferi-lo. A conexão dos testemunhos como as tecnologias comunicativas oferece outros significados à maneira como comumente conhecemos a manifestação desse ato de fala, a saber, de um indivíduo realizando uma longa narrativa sobre a ação de Deus em sua vida para um público que o assiste numa igreja. Como bem definiu a cantora e youtuber Priscilla Alcântara na divulgação de seu testemunho O livro de tudo:

Não, isto não é uma biografia. Que tal uma conversa? Em meio a tanta gente falando sobre si, acho que vale a pena uma conversa sobre tudo. Por que não contar a nossa visão sobre assuntos que são relevantes, mas que em um mundo de "eu, eu, eu" ninguém mais presta atenção?

Destaco que as artistas que compõem o cenário desta pesquisa são aquelas consideradas, em termos nativos, “de fora para dentro" (De Paula, 2007, p. 56), ou seja, celebridades provenientes do meio secular - onde já eram nacionalmente reconhecidas - e que, ao se converterem, passaram a se apresentar como artistas evangélicas. Baby do Brasil, Joana Prado, Léo Áquilla, Mara Maravilha, Natália Nara, Perlla, Sula Miranda, Valéria Valenssa, entre outras, são alguns

1 Este artigo é resultado de uma pesquisa por mim coordenada e intitulada "Testemunhos e transformações: narrativas, emoções e moralidades femininas na conversão religiosa de artistas populares", financiada pela Fundação de Amparo à Pesquisa do Estado de Minas Gerais (Fapemig) e pela Universidade Federal de Juiz de Fora (UFJF). Agradeço imensamente ao empenho e carinho da equipe de iniciação científica envolvida no projeto: Camila Oliveira, Caroline Mendonça, Helena Carvalho (IC/Fapemig), Luiza Vieira Godinho (Vic/UFJF), Maria Luiza Ramos (IC/Fapemig), Nathalia Magalhães, Rita Ramin, Tainara Silva, Thaís Melo (Bic/UFJF), Vanessa Fávero (Vic/UFJF), Victoria Junqueira (Bic/UFJF), Vinícius Farage e, in memoriam, ao saudoso Nicholas Domingues. 
exemplos das artistas cujos processos de construção de seus "novos lugares" no mundo das artes foram acompanhados. ${ }^{2}$ Não estou tratando neste trabalho, portanto, das celebridades que conquistaram espaços de destaque no meio evangélico seguindo um "movimento de dentro para fora" (De Paula, 2007, p. 56), caso típico das cantoras que surgem nos corais e atividades de igrejas, geralmente envolvidas desde a tenra infância com o sagrado, e que se tornaram figuras reconhecidas em território nacional a partir de suas fortes conexões com as religiosidades.

Usando um conjunto heterogêneo de fontes testemunhais, será discutida neste trabalho, com base em um estudo de caso, a trajetória artístico-religiosa da modelo Andressa Urach. ${ }^{3}$ Todo o material impresso e audiovisual levantado para o artigo nos guiará a pensar as ressignificações do conteúdo testemunhal na contemporaneidade. Além disso, nos deixará claro o quanto o universo da família torna-se importante no auxílio da construção dessas novas narrativas testemunhais. Estas serão observadas enquanto estilos discursivos capazes de transitar entre diferentes contextos midiáticos graças a uma série de conexões estabelecida entre aquele que narra e sua parentela, o que nomearei de corrente midiática da fé. Isso porque a necessidade de uma intensidade na experiência de conversão pentecostal torna a família importante marco narrativo dessas histórias, por se oferecer à religião - juntamente com o gênero e a sexualidade - como matéria-prima para a produção do ethos intenso imprescindível a trajetórias que pregam a mudança (Duarte, 2006; Duarte; Gomes, 2008; Gomes, 2006).

Por fim, cabe ressaltar que a frutífera "transpolinização" (Fonseca, 2003, p. 17) de ideias entre os campos de estudo de gênero e do parentesco permite observar as redes familiares das artistas menos por um viés "genealógico" e universalista típico das abordagens das teorias clássicas e mais por um enfoque analítico que explicita suas variadas formas de conexão e intercâmbio com as complexas dinâmicas tradicionalmente relegadas às áreas da economia, da

2 Por conta de uma preocupação com as questões de gênero e das vivências das feminilidades no mundo evangélico contemporâneo, a pesquisa debruça-se analiticamente apenas sobre as trajetórias de artistas mulheres cisgêneras ou transgêneras.

3 Sobre o uso das histórias de vida e da biografia na antropologia, bem como a realização de etnografias person-centerded de artistas populares, ver Bispo $(2015,2016 \mathrm{~b})$. 
política e - mais especificamente no caso deste trabalho - da religião (Fonseca, 2003, 2007; Piscitelli, 1998). Portanto, o parentesco será pensado como uma questão empírica, observando os contextos e modos como as artistas fazem "uso" de seus laços familiares para o desenvolvimento de seus testemunhos midiáticos.

\section{Testemunhos e religiosidades}

É recorrente na literatura especializada a tentativa de desvincular a prática testemunhal de suas dimensões mais popularmente conhecidas, ou seja, os testemunhos que são comuns nos contextos cristãos e cuja imagem-estereótipo é a de um indivíduo num templo realizando presencialmente uma longa narrativa sobre a ação divina em sua vida (Duarte; Dullo, 2016; Seligmann-Silva, 2005). Aponta-se, assim, para a presença da prática testemunhal no âmbito da política, do direito e mesmo como uma preocupação de diferentes campos do conhecimento científico, tal como a psicanálise ou mesmo a antropologia. Algo está em jogo nessa percepção expansiva da noção de testemunho, uma vez que ela ilustra muito mais do que uma mera constatação de sua ampla disseminação em nosso cotidiano. Percebê-lo para além da religiosidade, isto é, verificar suas fronteiras para com outras instâncias ditas laicas, é aferir o quanto a cultura ocidental moderna se fez e se faz a partir de certos atos de fala que, mesmo sendo identificados de imediato como elementos constitutivos do cerne das tradições religiosas cristãs, expandiram-se e disseminaram-se por inúmeras frentes sociais. Na verdade, nos alerta Dullo (2016, p. 87), tal múltiplo desdobramento aponta para uma perspectiva de que o testemunho não foi secularizado com $o$ passar dos tempos em nossa sociedade, mas, na verdade, de que ele é ao mesmo tempo cristão e secular. Testemunhar pode ser compreendido assim como ato de fala público que ilustra uma concepção moderna de pessoa - resultado de uma longa trajetória histórica que estabeleceu o indivíduo como dimensão fundamental da cosmologia ocidental - bem como "linguagens morais" (Martins, 2016) que constituem seus modos de vida tanto religiosos quanto seculares. Portanto, tais disseminadas práticas discursivas revelam os arranjos simbólicos e conceituais das maneiras como pensamos, agimos e nos tornamos pessoa na cultura ocidental moderna (Duarte, 2006, 2014; Duarte et al., 2006). 
Por outro lado, se quisermos atentar exclusivamente para essa prática no cristianismo, constatamos ser ela não só uma das formas mais antigas de transmissão da fé no Ocidente como também algo espraiado pelas mais diferentes dinâmicas religiosas. Comumente, o testemunho é pensado como um dos gêneros narrativos emblemáticos existentes entre os distintos atos de fala religiosos cristãos. Ao lado da prece, da pregação, do sermão e da confissão, por exemplo, o testemunho constituiu-se em uma modalidade discursiva de longa trajetória nos arranjos simbólicos, políticos e conceituais que conformam as maneiras de pensar e agir das religiões modernas ocidentais. Em nítido contraste com a confissão católica - vista como da ordem íntima, uma troca comunicativa privada e sigilosa capaz de revelar a "verdade" dos sujeitos a partir da possibilidade de se contar a alguém aquilo que não pode ser revelado a ninguém (Bispo, 2016a; Foucault, 1988) - a tradição religiosa protestante formulou um caráter público, comunitário, ao redor do testemunho. Afastando-se do aspecto institucional da confissão no catolicismo, no acesso a Deus por intermédio de um padre, Martins (2016, p. 37) nos descreve o testemunho protestante como valorizador da relação direta do homem com Deus, sendo aplicado tanto no exercício da atualização da "graça" - pela lógica da predestinação - como enquanto ferramenta de conversão.

No modelo evangélico encontrado centralmente nos cultos pentecostais na atualidade - e foco deste artigo - testemunhar significa verbalizar individualmente a uma coletividade a "libertação subjetiva" (Duarte, 2006) pela qual passam os novos fiéis das igrejas. Por meio deles, as pessoas se afirmam na fé e "atestam" sua fidelidade religiosa. ${ }^{4}$ São assim narrativas que contam na maioria das vezes as histórias de indivíduos que superaram certas adversidades em suas biografias por meio de intervenções divinas. Visando ser disseminadas o máximo possível, a publicização desses testemunhos parte da perspectiva de que é dever do sujeito em conversão "levar a palavra" a outras pessoas (Teixeira, C., 2011). Porém, mais do que uma intenção de conquista de novos fiéis a segmentos religiosos, a eficácia do testemunho necessita de ouvintes para que consiga se tornar "verdadeiro" ao próprio indivíduo que o profere (Machado, C., 2014).

4 Duarte e Dullo (2016, p. 14) nos lembram também uma outra típica modalidade discursiva testemunhal cristã, aquela que reafirma haver testemunhado um acontecimento, como os apóstolos que testemunham sobre os milagres operados por Jesus ao escreverem os Evangelhos. 
Por isso, muito fiéis constroem suas identidades religiosas não "apagando o passado", mas, sim, testemunhando aos outros sobre as agruras outrora experimentadas. Logo, entendê-lo tal como um gênero narrativo é constatar que as estruturas dos testemunhos tornam imprescindíveis a comunicação ampla e compartilhada e, portanto, pública, a fim de gerar a efetivação do longo processo de conversão pelos quais passam certas pessoas. É, portanto, o testemunho um ato informativo e performativo de uma trajetória individual repleta de sentidos, "em que se mobiliza a experiência vivida, a sua transformação em narrativa, e ainda a relação com uma plateia que escuta e sofre os objetivos ou efeitos concretos de sua prática" (Duarte; Dullo, 2016, p. 15).

\section{Mídia e testemunhos pentecostais}

Tendo tal clareza de como opera o fenômeno testemunhal nas vivências cristãs de modo geral, a proposta de agora em diante é pensar como os meios de comunicação estimulam a construção de outras formas testemunhais na atualidade, particularmente quando levamos em conta o competitivo cenário religioso brasileiro evangélico, sobretudo em seus segmentos neopentecostais, como a marcante presença na esfera pública da Igreja Universal do Reino de Deus (Iurd). As mídias em geral (os suportes impressos, audiovisuais, digitais, entre outros) têm se tornado lócus privilegiados para a formulação de novas maneiras de testemunhar que, se não recriam por completo o que é esse ato de fala - como a centralidade do autorreferenciamento e das histórias de vida de "transformação" -, o estimulam a adquirir diferentes e inusitadas possibilidades discursivas, além de expandirem a circulação de suas mensagens nesse contexto de disputa por fiéis.

O crescente número de evangélicos no Brasil tem permitido um novo olhar para os processos de conversão religiosa. Mafra (2000, p. 58) ressalta o quanto tais histórias de conversão indicam a adoção de novas vivências a partir da sensação de ruptura com um mundo procedente, geralmente por meio de um trânsito entre religiosidades de formação cristã. Além disso, destaca que o pentecostalismo tradicionalmente é visto como uma "religião da palavra" (Mafra, 2001, p. 56-57), isto é, a retórica, o saber se expressar pela linguagem são instrumentos centrais na cosmologia evangélica, fornecendo ao ato de nomear 
importantes efeitos e consequências na vida diária dos fiéis de tais vertentes religiosas. Além do mais, verificamos que os testemunhos de artistas evangélicas geram no cenário público aquilo que Dullo (2011, p. 107) nomeou de "indivíduo exemplar" a partir de sua experiência com jovens em projetos de promoção e "inclusão" sociais conduzidos por organizações não governamentais de forte base cristã. A exemplaridade individual de uma pessoa consiste em ser ela "alguém que é como deveria-ser". Isto é, alguém que parece seguir à risca na esfera pública certo projeto de vida considerado digno pelo olhar virtuoso das igrejas, exemplo capaz também de fazer outras pessoas se tornarem aquilo que elas são. Nesse processo, adere-se à normatividade expressada pelos comportamentos do "indivíduo exemplar" por meio de uma evangelização que se faz no estabelecimento de "relações exemplares" (Dullo, 2011, p. 125), algo que as artistas evangélicas conseguem tecer a partir de seus envolvimentos com os media em geral e o destaque que adquirem na sociedade como um todo.

Em que medida a disseminação de mensagens de artistas influencia a propagação de um ideário evangélico? Mais do que isso, como se efetivam as relações das religiosidades (neo)pentecostais com os meios de comunicação de massa? A bibliografia sobre religião e mídia aponta recorrentemente para as estratégias evangelísticas - particularmente de denominações como a Iurd - na organização e aquisição de canais e veículos importantes de comunicação de massa (Mafra, 2002; Stolow, 2014; Teixeira, C., 2011, Teixeira, J., 2014). O argumento recorrente é associar a mídia aos "usos" e "estratégias" de conquista de novos adeptos. Nesse caso, as artistas evangélicas seriam engrenagens de uma rotatória industrial-cultural muito maior, também de um projeto político.

Há uma marca contemporânea por detrás dos testemunhos que nos ajudam a pensá-los por entre as fronteiras esfumaçadas da prática religiosa do evangelismo, do entretenimento popular e das lógicas empresariais comerciais. Como bem aponta Stolow (2014), reverberam no campo religioso as drásticas transformações que acometem a vida política, econômica e social do mundo globalizado de hoje como um todo, "sobretudo no que diz respeito às revoluções que redefiniram nossa compreensão de 'mídia' em uma escala global” (Stolow, 2014, p. 148). Assim, um mercado de produtos culturais voltados para um "público religioso" ativamente consumidor soa menos deslocado quando pensado por entre as franjas das modernizações tecnológicas e as formas como as identidades se constroem inevitavelmente por meio dos media, inclusive as evangélicas, 
associadas inúmeras vezes a uma "tradição" que parece não ser possível de ser conciliada às novas tecnologias de informação e comunicação.

Assim, como qualquer proposta evangelizadora, as igrejas evangélicas buscam hoje publicizar ao máximo através da mídia as narrativas testemunhais de pessoas que são em algum grau influentes e conhecidas na sociedade. Ao longo da pesquisa etnográfica, me deparei com inúmeros formatos e estilos testemunhais produzidos pelas artistas sobre as quais procurava informações, ostensivamente emitidos e produzidos através de diferentes veículos de comunicação. Em relação aos produtos audiovisuais, eram recorrentes, por exemplo, os vídeos gravados de maneira profissional ou amadora - via smartphones ou tablets - e disponibilizados em plataformas como YouTube ou Vimeo tendo a celebridade como foco. Chamou-me também bastante a atenção a construção por parte dessas artistas de inúmeros "canais no YouTube", isto é, páginas pessoais nesta popular plataforma digital onde elas podem disponibilizar aos internautas vídeos feitos na maioria das vezes em suas casas. As imagens tratam de diferentes assuntos, porém é recorrente ali a existência de alguns vídeos-testemunhos - assim mesmo nomeados por elas - discursados pelas artistas sentadas numa cadeira de frente para um computador ou mesmo em um sofá ou cama. Esse estilo mais intimista e caseiro, isto é, fora do espaço religioso, faz-se também presente nos testemunhos do tipo "reportagem" - que são tanto disponibilizados na internet como também vendidos em formato de DVDs em lojas gospel ou nos cultos - em que a artista além de "dar o seu testemunho", na igreja ou fora dela, é entrevistada por alguma personalidade religiosa, geralmente um bispo, oferecendo ao espectador inúmeras imagens gravadas em sua residência ou em espaços públicos outrora frequentados e agora "proibidos", como boates, bares, casas de espetáculo ou prostituição.

Gostaria de eleger neste artigo um caso emblemático surgido durante a pesquisa de campo como fio condutor da análise. Trata-se da recente conversão à Iurd da ex-modelo Andressa Urach, conhecida nacionalmente por ter ficado em segundo lugar no concurso de "Miss Bumbum" e, por conta disso, ter feito participações em programas de televisão populares, revistas e sites de celebridades, na maioria das vezes devido aos seus relacionamentos amorosos com jogadores de futebol. Urach compõe os quadros daquilo que outrora classifiquei de "baixa classe artística" (Bispo, 2016a) para me referir a artistas que possuem sua visibilidade midiática majoritariamente entre os segmentos das classes populares 
e cujos dotes artísticos (música, dança, interpretação, etc.) são rotineiramente classificados pela crítica especializada ou mesmo pelo público como de "baixa cultura", trabalhos efetuados por "subcelebridades". Elas ocupam em geral atividades instáveis nos programas de auditórios e de humor na televisão, talk e reality shows, na indústria fonográfica e, não raramente, mantêm intensos ou porosos contatos (secretos ou não) com o mercado do sexo e do erotismo.

Entendemos que os testemunhos de Urach têm sido centrais na contemporaneidade para a "mediação" (Machado, C., 2014) da Igreja Universal com o público em geral. Eles têm emergido na cena pública como divulgares de seus ideais religiosos, além de instrumentos que servem para abrir as portas do mundo secular aos discursos evangélicos dessa vertente neopentecostal que se encontra em nítida expansão pelo país e pelo mundo.

Para se ter uma dimensão desse fenômeno, basta citarmos o livro-biografia-testemunho de Urach, que foi sucesso editorial no ano de 2015: Morri para viver: meu submundo de fama, drogas e prostituição. Levado às livrarias pela "laica" Editora Planeta, a obra ganhou tiragem inicial de 1 milhão de exemplares, vendendo cerca de 400 mil em apenas quinze dias: 50 mil em livrarias e 350 mil em locais religiosos. Além disso, Morri para viver alcançou a primeira posição de livro de "não ficção" mais vendido durante semanas do mês de agosto, mantendo-se ainda alguns meses na listagem indicadora das publicações de sucesso. Escrito em coautoria com o jornalista Douglas Tavolaro, essa parceria explicitamente revela os propósitos de expansão e conquista de novos fiéis por parte da Iurd: Tavolaro é o diretor de jornalismo da Rede Record de Televisão, além de sobrinho do bispo Edir Macedo, para quem já escreveu quatro biografias autorizadas. "Homem de confiança" da liderança maior da Iurd, o jornalista tem estimulado o profissionalismo em torno da exibição dos testemunhos audiovisuais na TV, ao mesmo tempo em que investe nas mídias impressas tradicionais.

Graças ao sucesso de seu livro, Urach passou a comandar um quadro dentro de um programa televisivo na Rede Record cuja proposta era contar "histórias de superação" tais como as dela. Além disso, a modelo também possui vídeos-testemunhos seus espalhados pelas redes sociais, além de um "canal no YouTube" intitulado Cozinhando com Andressa Urach. Ela, portanto, passou a circular pelos mais variados espaços midiáticos - dentro desse contexto de instrumentalização institucional pela Iurd de sua conversão - testemunhando sobre 
suas "transformações" para quem quiser ouvi-las. Sua vida artística tornou-se, essencialmente, compor-se enquanto persona pública a partir de uma corrente midiática da fé.

\section{Comunidade de sentimentos familiar}

"A que uma mulher ingênua e sem perspectivas, de família pobre do interior do Rio Grande do Sul, permite se submeter para alcançar notoriedade, fortuna e beleza?" (Urach, 2015, p. 13). É por meio de passagens como esta que Urach apresenta seu testemunho em formato de livro, Morri para viver, aos seus leitores. Pequenas sínteses biográficas são capazes de condensar a trama geral que será desenvolvida ao longo da obra. Trata-se de um recurso narrativo que instiga a todo instante a lembrança da "transformação" sofrida pela conversão, o típico "antes e depois" da narrativa testemunhal. "Rejeições, miséria, overdoses, depressão, conflitos em família, ameaças de morte, vingança, armações, holofotes, dinheiro fácil, ostentação. Ascensão e queda. A formação da personalidade de uma pessoa sem limites" (Urach, 2015, p. 16).

Há uma grande dramatização nos testemunhos e seus apelos ao extraordinário, de acordo com Machado, C. (2014, p. 47), que oferecem um grau de importância a certos casos que, outrora, eram tidos como banais, mas que, no ato comunicativo, tornam-se hipervalorizados por meio de uma narrativa melodramática. Observando o testemunho enquanto uma performance cênica, Côrtes (2007, p. 201) também salienta que tal prática recorrente oferece ao público "uma linguagem saturada de significantes e imagens exageradas, por meio das quais os dramas pessoais de cada um possam ter existência breve e fugaz, apenas até que dure a encenação".

A princípio, observamos em Morri para viver a ênfase no eu e na trajetória de vida pessoal de Urach, algo banal na prática testemunhal. Entretanto, o formato textual adotado pelos autores incentiva a participação de outros agentes nessa história, ilustrando essas novas possibilidades de exploração do testemunho no espaço público contemporâneo que venho aqui apontando. Como bem nos lembra uma importante bibliografia, toda a família acaba tendo que lidar de um modo ou de outro com as novas experiências religiosas de seus membros (Duarte, 2006; Duarte; Gomes, 2008; Gomes, 2006; Natividade; Oliveira, 2013). 
A conversão religiosa ecoa nos registros do parentesco e, por isso, faz-se presente com intensidade nos testemunhos. Porém o que verificamos nesses formatos midiáticos é que as histórias testemunhais deixam de ser plenamente individualizadas, no sentido de existir apenas um eu que fala de si e sobre seus parentes. O sujeito narrador como um realizador isolado ou, no máximo, um agente da ação de Deus na terra e apenas com ele em relação não é tão central assim nos testemunhos artísticos. Estes se tornam mais intensamente coletivizados através da mídia, atravessados por inúmeras redes de relações, majoritariamente familiares. Os parentes emergem com suas vozes e opiniões nos relatos dessas artistas, até mesmo nos formatos midiáticos tradicionais como os livros impressos. É claro que a parentela serve primordialmente para atestar a conversão das artistas, falando exclusivamente da subjetividade individualizada em destaque na narrativa, mas acaba compondo e dando ao testemunho uma marca mais relacional ao interpelar e motivar o sujeito a repensar sua vida para além dele mesmo ou de Deus.

O testemunho tem início nas dores e sofrimentos gerados pelo uso abusivo de hidrogel por parte de Urach ao final do ano de 2013, "uma das substâncias que apliquei para ganhar mais medidas nas nádegas e coxas em minha enlouquecida e inconsequente busca por medidas perfeitas e pela fama a qualquer preço" (Urach, 2015, p. 24). A internação da modelo na UTI de um hospital foi consequência de um caso grave de inflamação das pernas gerado pela presença excessiva dessa substância em seu corpo. Logo, não é a aleatória a escolha desse caso para iniciar o testemunho: é o momento preciso de sua própria trajetória que ela considera fazer a passagem do mal para o bem. Portanto, a doença, a proximidade da morte, os ferimentos e as cicatrizes são exaltadas como elo de lembrança com um passado tortuoso, a consequência que ficou na carne, "testemunhos orgânicos de sua quase morte" (Machado, C., 2014, p. 164).

A trama do ato no hospital é composta por vários personagens familiares. Os parentes são acionados a todo instante como um contraponto narrativo pela autora. Em contraste com o mal e a vida desregrada, sempre uma imagem do bem é formulada ao lado da família. Vejamos esta passagem bastante ilustrativa:

Era uma noite quente do dia 29 de novembro de 2014. Horas antes, havia retornado da praia de Quintão depois de passar o sábado com minha família na 
intenção de comprar uma casa para viajarmos no verão. Sempre adorei o litoral gaúcho. Saímos cedo de casa: eu, minha mãe, meu padrasto Dionatan, meu irmão Vinicius e meu filho Arthur, de nove anos. Era um dia ensolarado e a brisa soprava para todos os lados. Mas o tempo fecharia para mim. Na volta para casa, já na estrada e sentada no banco de trás do carro, passei a sentir fisgadas por toda a perna.

- Mãe, isso não é comum. Estou com muita dor. São umas pontadas estranhas na perna. Parece alguma coisa ruim acontecendo - comentei, já incomodada.

- Ligue para seu médico, filha. Ele pode te receitar um remédio mais forte para controlar isso que você está sentindo.

- Tudo bem, mãe. Não é nada - disse carinhosamente Arthur, encostando a cabeça no meu ombro. (Urach, 2015, p. 24).

O prazer de procurar uma casa de praia "em um dia ensolarado", quando "a brisa soprava por todos os lados", é substituído por fisgadas nas pernas e as dores ocasionadas por uma vida desregrada. Ao longo do ato, a mãe de Urach - Marisete de Faveri - aparece como figura-chave que é acionada de imediato nas narrativas da dor. Personagem zelosa, cuidadora e preocupada, faz de tudo pela saúde de sua filha. Ela é a responsável por conduzi-la até o hospital, por demandar melhor atendimento médico e mesmo rezar e interceder tanto junto aos especialistas quanto a Deus. Marisete já era frequentadora da Igreja Universal à época, "levada por minha avó Madalena de Faveri, já falecida" (Urach, 2015, p. 43). Pastores da igreja passaram a fazer visitas na UTI a convite da parentela feminina. Pesquisas sobre as feminilidades nas esferas urbanas do sagrado pentecostal apontam para o quanto o papel das mulheres é fazerem-se nas tramas testemunhais de "guardiãs das almas de todos que integram a família” (Machado, M., 2005, p. 389). Birman (1996b, p. 225) propõe de maneira semelhante serem elas "mediadoras exemplares entre as esferas sagradas e a mundanidade" por atuarem diretamente na tentativa de resolução das aflições que acometem seus filhos e maridos, que tendem a não frequentar as igrejas. Nas narrativas sobre o sofrimento maternal de Marisete, Urach reconstrói por meio do recurso a sua memória algumas falas que teriam sido proferidas por sua mãe no hospital e que ilustram essa atenção feminina às necessidades materiais e espirituais de seus grupos domésticos: "Meu Deus, eu não acredito! Não, não, não... não pode ser! Ela é forte, ela vai sair dessa! 
Minha filha vai sair dessa doutor!" (Urach, 2015, p. 33). Porém - e a isso gostaria de chamar a atenção do leitor - o ato performático é composto por testemunhos da própria mãe sobre o caso de sua filha, recolhido por meio de entrevistas:

Quando entrei na UTI pela primeira vez, vi a Andressa entubada e desfigurada. Quase não acreditei. Não era a minha filha cheia de vitalidade que estava ali. Esse não poderia ser o triste fim da vida dela. (Urach, 2015, p. 41).

Obrigada, Deus. Obrigada. Era a única frase que conseguia repetir ao lado do leito da minha filha. (Urach, 2015, p. 64).

Ao olhar para o lado, outras duas ou três enfermeiras da UTI estavam encostadas na parede limpando o choro. (Urach, 2015, p. 64).

O filho Arthur é descrito pela modelo como sendo o elo que garantiu sua negociação com Deus para que continuasse viva e mudasse seus comportamentos. "No lugar de dinheiro e sucesso, entraram o filho e a fé" (Urach, 2015, p. 16). A dedicação à maternidade é a moeda básica de troca para sua "segunda chance". No entanto, mesmo sendo um personagem central na narrativa de Urach, ao longo da obra não há depoimentos da criança. Entretanto, discursos imagéticos o colocam no cerne do testemunho. Fotografias mostram Andressa cuidando "zelosamente" de seu filho: tratando de seus cabelos dentro de casa; na rua oferecendo afagos ao garoto ou levando-o à escola. O espaço público agora é preenchido por imagens familiares. Isso porque as fotografias do filho possuem o mesmo propósito das falas da mãe de Urach acima transcritas: atestar a "transformação" da modelo por meio de uma participação mais ativa e integrada de outros no ato de fala testemunhal, algo garantido pelas propriedades textuais da narrativa escrita ou pelos recursos imagéticos das tecnologias da atualidade.

Na reconstrução de seu passado, Urach dá também atenção especial e muitas páginas de seu livro à conversão de seu primo Pablo à Iurd, datada de 2010. Considerado por ela como um "ex-bandido", traficante "violento" e dedicado a uma "longa vida na criminalidade" (Urach, 2015, p. 44), as lógicas agonísticas radicais, o ethos viril e a vida intempestiva típica dessas trajetórias masculinas 
ganham relevo na narrativa da modelo, ${ }^{5}$ contrastando com seu perfil de mulher outrora despudorada e sem limites. Estão em xeque, portanto, situações que põem a identidade de Pablo enquanto homem à prova, capazes de gerar desconforto e a procura por comunidades religiosas. "A fé viva que resgatou meu primo do crime poderia me salvar do coma" (Urach, 2015, p. 43). E Pablo também participa discursivamente do livro, contando sobre os sustos, crueldades e experiências que quase o levaram à morte no passado: "Tentei ser feliz no mundo do crime, mas não teve como. Uma hora, a conta chegou" (Urach, 2015, p. 45). ${ }^{6}$

Nesse sentido, verificamos que as mídias em geral se prestam a formular um circuito de sentimentos ao redor da pessoa convertida, garantido pelas figuras familiares que trocam afetividades entre si e estabelecem conectividades para com aquele que testemunha. Marisete, Arthur e Pablo exemplificam a formação desse circuito emotivo ao redor de Andressa. A família enquanto uma unidade autocontida (autônoma ou isolada) - como bem questiona Fonseca (2007, p. 13) em certas análises dos estudos de parentesco - não se sustenta diante das conexões afetivas por ela instituídas através dos veículos comunicacionais. Appadurai (1996) desenvolveu o conceito de "comunidade de sentimentos" justamente para se referir a uma rede de indivíduos que, através dos meios de comunicação, compartilham entre si determinadas configurações subjetivas e emocionais, "um grupo que começa a se imaginar e se sentir juntos" por e através dos recursos garantidos pelos veículos comunicacionais (Appadurai, 1996, p. 7, tradução minha). Nos âmbitos midiáticos religiosos, podemos pensar tal comunidade proposta por Appadurai como uma corrente midiática de fé capaz de trazer uma maior relacionalidade e conectividade para dentro dos testemunhos por meio de um processo que é fruto das interpelações emotivas de certos sujeitos sobre aquele que descreve sua vida.

Nota-se a partir do que foi exposto que os recursos garantidos pelas mídias tornam mais vívida a relacionalidade entre os parentes, indo além daquilo

5 Pesquisas sobre a conversão de bandidos ao pentecostalismo são recorrentes no âmbito da antropologia urbana. Ver, por exemplo, Alvito (2001); Côrtes (2007); Vital da Cunha (2008); Teixeira, C. (2011) e Machado, C. (2014).

6 Machado, M. (2005) chega a classificar o processo de conversão masculina ao pentecostalismo como sendo uma "androginização" ou "domesticação dos homens", tendo em vista que ela promoveria uma mudança drástica nesse ethos viril, em que ser "pai de família", "pacato", "dedicado ao lar" e "sexualmente controlado" tornam-se características imprescindíveis do novo homem transformado (Machado, M., 2005, p. 389). 
que o convertido comenta sobre eles, fazendo estes outros falarem também. Gera-se com isso uma corrente testemunhal de fé que engrandece a prática comunicativa da artista. Isso porque são na maioria das vezes os laços de parentesco e vizinhança que compõem a relacionalidade testemunhal. Pais, mães e maridos se fazem presentes em tais narrativas. É a partir justamente da interpelação de um pai/mãe/marido que o testemunhador se constitui e é constituído como um novo sujeito. A corrente de fé se inicia e é estimulada pelo testemunhador quando este se percebe como "transformado" a partir da fala desses outros envolvidos numa "comunidade de sentimentos" religiosa com ele. Diante disso, vemos assim veículos comunicacionais perpassando as dinâmicas da vida familiar de certas artistas evangélicas, não agindo "sobre" essas redes e meramente manipulando-as, mas atuando como "coprodutoras do contexto" (Fonseca, 2007, p. 28). Temos, portanto, diferentes tecnologias de comunicação atuando diretamente na "coprodução" da vida social em família, garantindo os elos que conectam pessoas e sentimentos a também outras pessoas e seus sentimentos.

Ainda no primeiro ato do livro de Andressa, chamou-nos bastante a atenção o uso dos discursos médicos na confecção da trama narrativa. Indo além dos parentes e amigos, infectologistas, cirurgiões plásticos, cardiologistas e enfermeiros atestam a gravidade da doença da modelo e o sofrimento por ela vivido durante os dias em que passou no hospital ao comprovarem "tecnicamente" os efeitos colaterais de cirurgias plásticas e o uso de substâncias nocivas ao organismo como o hidrogel, compondo e aumentando a corrente midiática de fé que se constitui em torno de Andressa.

Andressa estava completamente vermelha, dos seios até os pés. Era uma infecção grave dos tecidos conhecida como celulite, não aquela que todos conhecem como pequenos furinhos na pele das mulheres, mas sim também chamada de erisipela. O corpo dela estava duro, empastado, inchado - detalha o dr. Pedro. (Urach, 2015, p. 32-33).

Imagine uma esponja mergulhada em um balde com água. Levante essa esponja. O que acontece? A água escorre toda para a parte de baixo da esponja. Foi isso o que aconteceu com o hidrogel utilizado pela Andressa. Ele escorreu para a parte baixa das coxas dela - explica o cirurgião plástico Júlio Vedovato. (Urach, 2015, p. 52). 
Sempre encontrava algumas colegas de trabalho pelos corredores do hospital que riam de Andressa. Algumas diziam: "cuidado para ela não te bater ou cuspir no seu rosto". Eu brigava com elas e dizia que Andressa também merecia uma segunda chance - recorda Deise Ourique, técnica em enfermagem que me acompanhou o maior tempo na UTI. (Urach, 2015, p. 64).

Logo, não se trata apenas de destacar neste trabalho como as vozes dos outros são incorporadas nas falas daqueles que testemunham, mas perceber como elas realçam a importância da interpelação e afetação de uns sobre outros no processo de pôr-se a falar de sua conversão. Quando observamos, por exemplo, a ativa participação de agentes de saúde no testemunho de Urach - no mesmo patamar que seus familiares "de sangue" - questionamos as próprias premissas biológicas que subjazem as definições tradicionais de parentesco. Inspirados em Carsten (2014) e suas perspectivas de relacionalidade do parentesco ("relatedness"), constatamos que a corrente midiática da fé estimula a produção de laços afetivos, mesmo que difusos e instáveis, entre as artistas e diversos outros sujeitos, produzidos não somente a partir da "troca de substâncias" - tais como o sangue e o leite entre mães e filhos -, mas também por meio de outras formas interativas e de afetação recíprocas. Vemos emoções de fé em circulação serem trocadas pela mídia no seio de um conjunto de pessoas que relembra coletivamente entre si e para ouvintes a experiência de terem acompanhado uma trajetória de "mudança" no passado.

\section{Na igreja, na sala, na cozinha}

O sucesso de Morri para viver tornou Urach uma celebridade evangélica. Seus testemunhos em igrejas e nas mídias em geral tornaram-se frequentes. A equipe da pesquisa e eu identificamos duas influentes falas da modelo no canal YouTube. Somadas, chegam a quase 3 milhões de visualizações em dois anos. A mais vista ocorre no Templo de Salomão da Iurd em São Paulo. ${ }^{7}$ Ela fala para uma imensa plateia ao lado de um bispo e de sua mãe Marisete. Apesar desta última nada declarar no microfone, a todo instante a modelo estimula uma corrente

7 Ele pode ser acessado por este link: https://www.youtube.com/watch?v=tRKURAvyI5w\&t=326s (acesso em: 25/09/2017). 
de fé familiar. "A minha mãe sabe de tudo em minha vida", "a minha mãe é testemunha disso" e "minha mãe aqui do meu lado, fiel a Deus" são frases que pontuam o discurso, cujo objetivo simbólico é trazer a presença maternal como prova incontestável da mudança. A mãe que acompanha a filha pecadora ao templo atesta apenas por meio de sua presença física as agruras sofridas por ela, instaurando em público a "comunidade de sentimentos" que os testemunhos midiáticos de Andressa estão a todo instante estimulando ao redor dela.

O vídeo é profissional, produzido pela equipe da Iurd para a internet. Ele não é estático, captando apenas as imagens da testemunhante no púlpito em close, algo comum nesse tipo de trabalho. Tanto a mãe quanto o bispo dividem com a modelo a atenção visual do espectador. Além disso, há inúmeros takes da plateia que assiste a tudo em silêncio. Recursos de gravação procuram dar a dimensão do número de pessoas por meio do afastamento lento da lente do rosto de Andressa até o pleno aparecimento da massa-público por meio de uma câmera que capta à distância todo o templo. Chama a atenção a desativação por parte da equipe da Iurd da sessão de comentários do vídeo. Não é possível fazer qualquer escrito sobre aquilo a que se assiste, recurso comum no YouTube.

O segundo vídeo é de Urach em uma Igreja Universal em Macapá. ${ }^{8}$ Disponibilizado por um bispo, ele não conta com os recursos visuais daquele produzido profissionalmente. $\mathrm{O}$ ato de fala segue pela mesma tônica: a modelo apresentando a "velha Andressa" e contrastando-a com a "nova Andressa". Centenas de comentários de internautas seguem abaixo do vídeo. Em sua maioria, reconhecem-no como um "testemunho forte" e apoiam a conversão da modelo.

Tem que ser uma pessoa muito corajosa para admitir os erros e dar a cara a tapa pro mundo.

Mudou! Tanto fisicamente quanto espiritualmente, que vc siga sua caminhada confiando em Deus sempre!!!

Que testemunho forte! Deus é maravilhoso que ele te fortaleça e te ajude sempre na caminha cristã!

8 Link para o segundo vídeo: https://www.youtube.com/watch?v=kNDQkiGFA6s\&t=83s (acesso em: 25/09/2017). 
A fala de Urach também provoca nos espectadores certas sensibilidades, além de suscitar que os ouvintes narrem experiências semelhantes àquelas contadas no testemunho por meio de textos escritos.

Fico toda arrepiada, ouvindo esse testemunho, e vendo o agir de Deus na vida do ser humano.

Chorei varias vezes, muito emocionante! felicidades Andressa.

Eu estou como ela sem me dá bem com pessoas e sou muito ra[n]corosa fui abandonada pela minha mãe aos 5 anos e sofri muito na mão de madrasta.

Por outro lado, os comentários negativos ao vídeo seguem exemplarmente a típica desconfiança que ronda os relatos testemunhais, uma vez que a condição de "mulher da vida" pode ser vista como algo que a experiência individual de se converter não seria capaz de alterar. Inúmeras "tretas" virtuais eclodem nesse sentido. Os internautas debatem entre si sobre a veracidade da fala de Andressa, desconfiando de suas histórias e mesmo de sua capacidade de mudança. Porém, como bem pontua Côrtes (2007, p. 190), a pergunta sobre a boa ou má fé do testemunho não cabe tanto assim porque as narrativas são formuladas justamente na liminaridade desses dois polos, sendo sua eficácia produzida pela mistura do "acreditável" com o "inacreditável". Um bom testemunho aparenta ser falso e verdadeiro ao mesmo tempo, gera esse tipo de inquietação em quem o escuta. A potência e popularidade das comunicações pessoais de Urach está no fato de ela enquanto artista saber passear por tais fronteiras da veracidade, angariando espaços midiáticos ao conseguir suscitar nos outros tanto admirações quanto desconfianças.

Daniele: sempre que ela conta essas histórias é sempre do mesmo jeito, com as mesmas palavras, parece até um roteiro estudado e decorado.

Fran Jordão: Testemunho não muda... testemunho de vida verdadeira nunca muda. True Dare: E pelo visto vc continuará pra sempre sendo so uma Burra!! Né Fran Jordao!!

Daniele: True Dare, verdade vc disse tudo. Fora que ela sempre começa a falar e jaja começa a chorar. O mas engraçado é que nunca ela teve culpa d nada, se ela 
foi esse lixo de ser humano que ela "era" sempre foi por causa d algo ou alguém. Ela sempre foi esse lixo d pessoa porque quis, engraçado tbm que quando ela não era evangélica ela vivia bem sorrindo e agora conta só chora mta mentira hipócrita!!!

Bruno: ue gente, foi a realidade, ela viveu isso, vai contar mais o que?

Angela Longhi: Bruno Furtado pois é. Povo gosta de julgar.

Thamara Rodrigues: olha Dani um testemunho impactante desse. Vc tá olhando isso. ela tá refazendo a história dela... e vc preciza fazer a sua. O que que vc tem pra contar??????

Bruno Izidio: Quando e verdade, pode passar 40 anos e vamos contar dá mesma forma. Mas quando é mentira... não conseguimos lembrar.

Daniele: Thamara Rodrigues vai te catar garota!! sua mal educada!!

Assim, os vídeos das artistas nos oferecem novidades também sobre o testemunhar hoje, incrementando a corrente midiática da fé com as vozes daqueles que o escutam. Primeiramente, percebemos que a relação de comunicação entre falante e ouvinte tem suas fronteiras modificadas. Quem ouve torna-se mais agente frente àquele que fala. Ele comenta e interpela mais diretamente a pessoa, além de agir sobre suas narrativas e confeccioná-las ao seu prazer, "curtem" ou "não curtem" certo vídeo, tecem avaliações sobre a história da artista, julgam sua veracidade. A autoridade narrativa é descentrada. É claro que não temos aqui a visão "polifônica" tão bem defendida por Clifford (2008) nas propostas narrativas para os textos antropológicos, por exemplo. Não se trata de um testemunho que nasce de uma interação dialógica, arena de diversidade e múltiplas vozes. O narrador concentra o discurso público sobre si. Porém o testemunho adquire seu significado discursivo através de uma interlocução que ocorre em um contexto digital, onde as ferramentas de trocas e compartilhamentos permitem uma negociação maior em torno daquilo que é falado. Como bem nos alertam Duarte e Dullo (2016, p. 15), "o testemunho deve emergir da ampla teia de significação e comunicação em que se instaura e mobiliza seus efeitos, por meio de incidências relacionalmente personalizadas". Isso significa pensá-lo também nas interações que geram com o público por meio do mundo virtual e suas formas específicas de comunicação, como as conversas e típicas "tretas" que as manifestações de opinião hoje promovem na internet. 
E mais: no melhor estilo do pastiche, os internautas agem confeccionando novas narrativas perante aquilo que escutam e observam das artistas. Atuam por meio da edição, combinam imagens, fazem colagens e montagens, os conhecidos memes virtuais que circulam nas redes sociais. ${ }^{9}$ Tais recursos rotineiramente possuem um tom de escárnio e deboche para com a conversão das artistas, porém acabam reafirmando pelo humor o "antes e depois" tão bem fundamentados nas tramas do sofrimento testemunhais. Eles colaboram na construção da imagem midiática da artista enquanto uma mulher evangélica, convertida e regenerada, portanto, auxiliam na perpetuação e propagação da eficácia em torno da corrente de fé do ato de testemunhar.

A produção fílmica oferece uma dimensão espacial que outrora não existia nos testemunhos ou, pelo menos, não se fazia tão importante para sua confecção narrativa. A oralidade que é o foco dessa comunicação tem sua centralidade colocada em xeque pelas espacialidades. Foucault (2001) já nos advertiu que "a época atual é, antes de mais nada, a época do espaço", referindo-se ao fato de que o "espaço" teria substituído o "tempo" como princípio de inteligibilidade das formações culturais contemporâneas. Assim, quartos, camas, sofás, estúdios, locais "da perdição" e "da redenção" compõem não só como cenários o testemunho, mas também agem para a compreensão e significação do próprio. Por meio do audiovisual, territórios específicos tornam-se vívidos - são personagens que constituem intrinsicamente o testemunhante - demonstrando que existe na atualidade uma produção social dos espaços substituindo a mera ideia de "localização física" de alguma coisa em algum lugar. O testemunho torna-se cada vez mais um discurso oral, imagético e territorialmente situado.

A tópica da espacialidade fica clara ao observarmos o "canal do YouTube" chamado "Cozinhando com Andressa Urach". A proposta da plataforma é ensinar jovens garotas a cozinhar, através da apresentação de receitas práticas. “Oi, meninas!" é como rotineiramente a modelo se refere a suas interlocutoras. ${ }^{10}$ A "velha Andressa" era uma mulher pouco dedicada a esses serviços, diz, porém

9 Meme se refere a uma imagem ou expressão que "viraliza" nas redes sociais, isto é, seu uso se espalha muito rapidamente pela web. Essas imagens ou expressões são usadas de modos repetitivos em diferentes contextos de forma majoritariamente jocosa.

10 Disponível em: https://www.youtube.com/channel/UCuxV-qqrGe5hnhS_x6j5IdA/videos (acesso em: 25/09/2017). 
a "nova Andressa" pretende executá-los com ardor, ensinando meninas a serem desde novas dedicadas ao lar. Seu esposo Thiago surge em um vídeo do canal ao lado da modelo, ambos sentados no sofá da sala do casal, para contar como era a "antiga Andressa" na cozinha. Enquanto ela testemunha rememorando suas poucas habilidades - "até hoje minha sogra lembra como era ruim a minha lentilha, meninas!" -, o marido ratifica:

Faltava um pouco de esforço da sua parte, Andressa! Comíamos muito miojo em casa, muita pipoca. A minha Andressa de antes era uma Andressa infantil, imatura e insegura. Não tinha a mínima consciência do que era certo ou errado. A Andressa de hoje é totalmente diferente. Não tem mais acessos de loucura. É muito mais fácil de se lidar. É curiosa, está aprendendo a cozinhar, a fazer coisas diferentes. Hoje o feijão dela está uma delícia, até a lentilha melhorou.

Ela completa, em diálogo e risos com ele:

Minha família não me educou para respeitar o meu marido. Eu brigava até por uma toalha molhada em cima da cama, né amor? Olha quantas mulheres gostariam de estar tirando uma toalha de cima da cama! Esposa, pense, pare! Não brigue por causa de uma toalha na cama. Hoje eu junto com muito gosto, né amor? Adoro tirar toalha de cima da cama.

Além da sala, a cozinha da casa da modelo torna-se personagem desses experimentos. Em princípio, mais um canal de artistas executando alguma atividade e exibindo-a para seu público seguidor. Entretanto, há um forte "teor testemunhal" - no sentido proposto por Seligmann-Silva (2005) - em todos os vídeos culinários de Andressa. Segundo Gabler (1999, p. 117), todo acontecimento é desculpa para uma celebridade hoje exibir aos outros sua "vida-filme" e, refletindo aqui a partir das artistas evangélicas, estas se tornam "novelas ambulantes", visto que todas as suas notícias e aparições subordinam-se necessariamente a suas histórias de transformação.

Logo, entre receitas para um "franguinho rápido assado" ou de uma "maionese caseira suculenta", o lar em exibição de Urach serve para atestar a conversão da modelo e a mudança que é conquistada aos poucos depois de muito sofrimento: sair da rua e seus espaços de perdição para uma vida doméstica 
não seria uma tarefa fácil, torna-se uma verdadeira missão. As combinações de ingredientes são às vezes difíceis, confunde-se colher de chá com a de sopa, não se sabe bem o nome dos ingredientes a serem misturados. A artista passa por pequenos percalços a fim de executar com sucesso as receitas, mas tudo isso compõe o trabalho intenso para a manutenção de uma vida em fé. "Eu ainda estou aprendendo a cozinhar", diz, enfatizando sempre os cursos de culinária com os quais anda envolvida. Birman (1996a), Mafra (2000) e Teixeira, C. (2011) são enfáticos em realçar que a conversão não é uma transformação abrupta que se dá após o ápice de um processo dramático, transformando subjetividades de maneira mecânica e direta. Não sendo algo em definitivo, é uma experiência resultado de um processo de aprendizagem, "mediado por uma trama complexa e longa" (Teixeira, C., 2011, p. 150) - portanto, uma "passagem" (Birman, 1996a) - que nos permite perceber as mediações sociais e simbólicas (como certos rituais e práticas) bem como os mediadores que tornam possível a dita conversão. O processo contínuo e tortuoso de Andressa é construído por ela, enquanto celebridade, aos olhos de todos em seu canal graças a uma corrente midiática de fé que constrói ao seu redor. Semanalmente posta vídeos caseiros, por ela mesma editados, ao lado de sua amiga responsável pela gravação e em conversa constante com sua chefe de cozinha, seus utensílios, fogão e "hortinha" doméstica. Os cachorros passam pela câmera e são motivos para brincadeiras. Sente-se desafiada pelo ato de cozinhar, demonstrando o quanto após "aceitar Jesus" o processo de purificação é incessante.

\section{Conclusões: a persona testemunhal na mídia}

Como se efetivam as relações das religiosidades evangélicas com os meios de comunicação de massa? Ao longo deste artigo busquei demonstrar que a sociedade brasileira hoje nos conduz a desafios que exigem o estudo de novos objetos de pesquisa mediante o emprego de distintas ferramentas conceituais. Propus-me a analisar neste texto as pluralidades de modelos de experimentar o ato de testemunhar na atualidade, assumindo a sua flagrante associação com as novas tecnologias e as reconfigurações que estas vêm imprimindo às dinâmicas mais banais das comunicações de massa no Brasil. Salientei que, através da formulação de uma corrente midiática da fé, artistas evangélicas acrescentam 
novos sentidos contemporâneos ao testemunho, oferecendo a ele uma maior relacionalidade por meio de um processo que consiste em trazer à tona a presença viva de seus parentes, vizinhos, conhecidos e fãs na adoção de suas novas maneira de viver.

Por fim, a partir do material aqui apresentado através da trajetória de Andressa Urach, pode-se constatar como as artistas evangélicas vão se tornando aos poucos verdadeiras personas testemunhais, isto é, figuras midiáticas cuja participação na esfera pública por meio dos veículos de comunicação se dá pela ação constante em prol da promoção da transformação, qualquer que seja o propósito de suas atuações nas distintas mídias. Seguindo as preciosas pistas das clássicas concepções maussianas em torno da necessidade de se problematizar e situar culturalmente a noção de pessoa, em outros trabalhos (Bispo, 2015, 2016a) desenvolvi o conceito de persona midiática para me referir à atuação de artistas na indústria cultural contemporânea que parecem cumprir certos "papéis" no contexto das dinâmicas do entretenimento tal como metaforicamente o desempenho de "personagens" e o uso de "máscaras rituais" em certos "dramas sagrados" analisados por Mauss (2003, p. 382). As personas midiáticas são performances recorrentes na arte comercial popular de hoje, cujas personagens e suas máscaras se configuram primordialmente através de uma articulação - e não na dissociação como comumente se pensa - entre a imagem pública produzida em torno de determinados artistas e suas respectivas trajetórias sociais, suas vidas ditas mais privadas, aquilo que vai além das imagens frutos de seu trabalho artístico.

Quando o testemunho de artistas evangélicas se alastra para além do ato de contar as histórias de sofrimento no púlpito da igreja - de situações que poderíamos considerar como sendo "privadas" e "pontuais" - a dinâmica espetacular da persona testemunhal torna tais artistas testemunhos de si mesmas, além de instrumentos de propagação dos ideários das igrejas pentecostais. Elas são personagens cumprindo os papeis de suas próprias histórias de vida, emergindo midiaticamente como sujeitos reduzidos a narrar a sua trajetória de conversão a todo momento.

Segundo o diagnóstico sobre a contemporaneidade de Gabler (1999), a realidade social de hoje se converteu em uma grande encenação - a vida se transformou num filme mais fascinante do que qualquer obra de ficção - graças às lógicas de produção da indústria do entretenimento. Em suas palavras: "A vida 
não existe para terminar num livro; quando a vida é um veículo de comunicação, os livros e todas as outras formas imaginativas existem para terminar num mundo" (Gabler, 1999, p. 12). Para o autor, as celebridades na atualidade tornam-se exemplares menos por um feito ou habilidades realizadas, mas por serem modelos de como conseguir teatralizar a própria vida, pessoas que detêm a "arte" de tornar-se entretenimento. Articulando isso à prática da perona testemunhal que aqui exponho, vemos uma classe de artistas hábeis em captar e manter a atenção pública graças à sua capacidade de narrar a "mudança", e cuja consagração se faz justamente não só por apresentarem o melhor espetáculo possível de suas novas vidas evangélicas, mas também por saberem expor a produção e confecção desse próprio espetáculo a todos, aquilo que Gabler (1999, p. 97) nomeou de "efeito Heisenberg". Não é à toa o prestígio adquirido por Urach entre as lideranças da Iurd: suas habilidades de fazer-se constantemente uma persona que testemunha deu a ela espaços midiáticos nunca antes alcançados em sua instável trajetória artística de modelo e dançarina, tornando-se um trunfo da Iurd em suas disputas com outras vertentes pentecostais no contexto do cenário religioso evangélico brasileiro.

Através da persona testemunhal, a dimensão temporal é capaz de fazer apresentar visualmente pelo testemunho aquilo que se foi. $\mathrm{O}$ acontecimento do passado é usado de maneira estratégica a fim de que reapareça temporalmente no presente por meio do espetáculo, dando a ele um outro sentido social. Por isso podemos afirmar que a persona testemunhal consiste em percebermos a artista tornar-se o seu próprio testemunho em público, ela é personagem de si mesma. Teixeira, C. (2016) propõe algo semelhante quando diz que - a partir de seus interlocutores "ex-bandidos" - "ser um testemunho" é não bastar que certa pessoa convertida tenha histórias de conversão para contar. Trata-se necessariamente de sê-lo, no sentido de "comprometer-se com a própria narrativa construída, dando provas de que a 'transformação de si' é uma prática cotidiana, para que sua performance seja considerada autêntica e produza a valorização moral da pessoa" (Teixeira, C., 2016, p. 131).

Portanto, as trajetórias das artistas evangélicas vêm comprovando que "ser o testemunho", midiaticamente, é sustentar todo o conteúdo do seu passado a cada instante de destaque, a cada interação que estabelecem nas mídias em geral, através da formulação de uma persona midiática que é ela própria testemunho de si. As celebridades evangélicas interpretam a si mesmas 
e, relembrando Gabler (1999, p. 159), quando a carreira artística de alguém é apenas viver e saber expor isso, o sujeito torna-se ator de sua própria vida. As dinâmicas da indústria cultural religiosas nas quais estão envolvidas as artistas evangélicas convidam-nas e incitam-nas a serem apenas seus próprios testemunhos de fé quando diante dos holofotes, reduzindo-se a um repertório curto de características: alguém que fala publicamente sobre o seu passado sofrido.

\section{Referências}

ALVITO, M. As cores de Acari: uma favela carioca. Rio de Janeiro: FGV, 2001.

APPADURAI, A. Modernity at large: cultural dimensions of globalization. Minneapolis: University of Minnesota Press, 1996.

BIRMAN, P. Cultos de possessão e pentecostalismo no Brasil: passagens. Religião e Sociedade, Rio de Janeiro, v. 17, n. 1/2, p. 90-109, 1996a.

BIRMAN, P. Mediação feminina e identidades pentecostais. Cadernos Pagu, Campinas, n. 6/7, p. 201-226, 1996b.

BISPO, R. Por uma etnografia dos artistas populares: reflexões sobre personas midiáticas e biografias de celebridades. In: KOFES, S.; MÂNICA, D. (Org.). Etnografia e biografia: experiências com as diversas grafias sobre a vida social. Rio de Janeiro: Lamparina, 2015. p. 239-259.

BISPO, R. Rainhas do rebolado: carreiras artísticas e sensibilidades femininas no mundo televisivo. Rio de Janeiro: Mauad X: Faperj, 2016a.

BISPO, R. Tempos e silêncios em narrativas: etnografia da solidão e do envelhecimento nas margens do dizível. Etnográfica, v. 20, n. 2, p. 251-274, 2016b.

CARSTEN, J. A matéria do parentesco. R@U: Revista de Antropologia da UFSCar, São Carlos, v. 6, n. 2, p. 103-118, 2014.

CLIFFORD, J. A experiência etnográfica: antropologia e literatura no século XX. Rio de Janeiro: Editora UFRJ, 2008.

CÔRTES, M. O bandido que virou pregador: a conversão de criminosos ao pentecostalismo e suas carreiras de pregadores. São Paulo: Hucitec, 2007.

DE PAULA, R. "Os cantores do Senhor": três trajetórias em um processo de industrialização da música evangélica no Brasil. Religião e Sociedade, Rio de Janeiro, v. 27, n. 2, p. 55-84, 2007. 
DUARTE, L. F. D. Ethos privado e modernidade: o desafio das religiões entre indivíduo, família e congregação. In: DUARTE, L. F. D. et al. (Org.). Família e religião. Rio de Janeiro: Contracapa, 2006. p. 51-88.

DUARTE, L. F. D. Religião e conflitos morais na sociedade brasileira contemporânea. Debates do NER, Porto Alegre, n. 26, p. 69-84, 2014.

DUARTE, L. F. D.; DULLO, E. Introdução ao dossiê ‘Testemunho'. Religião e Sociedade, Rio de Janeiro, v. 36, n. 2, p. 12-18, 2016.

DUARTE, L. F. D.; GOMES, E. Três famílias: identidades e trajetórias transgeracionais nas classes populares. Rio de Janeiro: FGV, 2008.

DUARTE, L. F. D. et al. Família, reprodução e ethos religioso subjetivismo e naturalismo como valores estruturantes. In: DUARTE, L. F. D. et al. (Org.). Família e religião. Rio de Janeiro: Contracapa, 2006. p. 15-50.

DULLO, E. Uma pedagogia da exemplaridade: a dádiva cristã como gratuidade. Religião e Sociedade, Rio de Janeiro, v. 31, n. 2, p. 105-129, 2011.

DULLO, E. Testemunho: cristão e secular. Religião e Sociedade, Rio de Janeiro, v. 36, n. 2, p. 85-106, 2016.

FONSECA, C. De afinidades a coalizões: uma reflexão sobre a "transpolinização" entre gênero e parentesco em décadas recentes da antropologia. Ilha, Florianópolis, v. 5, n. 2, p. 5-31, 2003.

FONSECA, C. De família, reprodução e parentesco: algumas considerações. Cadernos Pagu, Campinas, n. 29, p. 9-35, 2007.

FOUCAULT, M. A história da sexualidade: vol. 1: a vontade de saber. São Paulo: Graal, 1988.

FOUCAULT, M. Outros espaços. In: FOUCAULT, M. Ditos e escritos: vol. III: estética: literatura e pintura, música e cinema. Rio de Janeiro: Forense Universitária, 2001. p. 411-422.

GABLER, N. Vida, o filme. São Paulo: Companhia das Letras, 1999.

GOMES, E. Família e trajetórias individuais em um contexto religioso plural. In: DUARTE, L. F. D. et al. (Org.). Família e religião. Rio de Janeiro: Contracapa, 2006. p. 191-218.

MACHADO, C. Pentecostalismo e o sofrimento do (ex-)bandido: testemunhos, mediações, modos de subjetivação e projetos de cidadania nas periferias. Horizontes Antropológicos, Porto Alegre, ano 20, n. 42, p. 153-180, jul./dez. 2014.

MACHADO, M. Representações e relações de gênero em grupos pentecostais. Estudos Feministas, Florianópolis, v. 13, n. 2, p. 387-396, 2005. 
MAFRA, C. Relatos compartilhados: experiências de conversão ao pentecostalismo entre brasileiros e portugueses. Mana, Rio de Janeiro, v. 6, n. 1, p. 57-86, 2000.

MAFRA, C. Os evangélicos. Rio de Janeiro: Zahar, 2001.

MAFRA, C. Na posse da palavra: religião, conversão e liberdade pessoal em dois contextos nacionais. Lisboa: Imprensa de Ciências Sociais, 2002.

MARTINS, I. Moralidades e atos de fala em serviços de apoio emocional: modalidades laicas da confissão e do testemunho?. Religião e Sociedade, Rio de Janeiro, v. 36, n. 2, p. 19-43, 2016.

MAUSS, M. Uma categoria do espírito humano: a noção de pessoa, a de "eu". In: MAUSS, M. Sociologia e antropologia. São Paulo: Cosac Naify, 2003. p. 367-398.

NATIVIDADE, M.; OLIVEIRA, L. As novas guerras sexuais: diferença, poder religioso e identidades LGBT no Brasil. Rio de Janeiro: Garamond, 2013.

PISCITELLI, A. Nas fronteiras do natural: gênero e parentesco. Estudos Feministas, Florianópolis, v. 6, n. 2, p. 305-322, 1998.

SELIGMANN-SILVA, M. Testemunho e a política da memória: o tempo das catástrofes. Projeto História, n. 30, p. 71-98, 2005.

STOLOW, J. Religião e mídia: notas sobre pesquisas e direções futuras para um estudo interdisciplinar. Religião e Sociedade, Rio de Janeiro, v. 34, n. 2, p. 146-160, 2014.

TEXEIRA, C. A construção social do "ex-bandido": um estudo sobre sujeição criminal e pentecostalismo. Rio de Janeiro: 7Letras, 2011.

TEXEIRA, C. O testemunho e a produção de valor moral: observações etnográficas sobre um centro de recuperação evangélico. Religião e Sociedade, Rio de Janeiro, v. 36, n. 2, p. 107-134, 2016.

TEIXEIRA, J. Mídia e performances de gênero na Igreja Universal: o desafio Godllywood. Religião e Sociedade, Rio de Janeiro, v. 34, n.2, p. 232-256, 2014.

URACH, A. Morri para viver: meu submundo de fama, drogas e prostituição. São Paulo: Planeta, 2015.

VITAL DA CUNHA, C. “Traficantes evangélicos”: novas formas de experimentação do sagrado em favelas cariocas. Plural, São Paulo, v. 15, p. 23-46, 2008.

Recebido: 27/09/2017 Aceito: 11/05/2018 | Received: 9/27/2017 Accepted: 5/11/2018 